\title{
Innovation in Government Services: The Case of Open Data
}

\author{
Zhenbin Yang and Atreyi Kankanhalli \\ Department of Information Systems, National University of Singapore, Singapore \\ \{zhenbin, atreyi\}@comp.nus.edu.sg
}

\begin{abstract}
Governments are initiating open data initiatives as a new approach where external stakeholders can play an increased role in the innovation of government services. This is unlike previous approaches of e-government service innovation where services are solely initiated and developed by the agencies themselves. However, despite public agencies actively promoting the use of their data by organizing events such as challenge competitions, the response from external stakeholders to leverage government data for innovative activities has been lacking. This raises the question about the reasons inhibiting the interest to innovate using open data. Yet, the existing literature points to a lack of understanding about external stakeholders' willingness to innovate with the data provided. Motivated thus, this paper aims to identify the antecedents of the willingness of external stakeholders to innovate with open data. We propose the use of the case study methodology for this purpose.
\end{abstract}

Keywords: Open data, eGovernment, open innovation, open government data.

\section{Introduction}

Since the launch of the first open data portal (data.gov) by the United States government in 2009 to provide a single point of access to data from multiple public agencies, an increasing number of countries have launched similar open data initiatives (e.g., UK, Singapore, Australia, Chile). Open data involves the disclosure of raw data by government agencies that they have collected for public consumption. By leveraging the advancements in ICT and the Internet, government agencies which are commonly viewed as among the largest creators and collectors of data have the potential to share a multitude of information across many domains, e.g., finance, transport, environment (Janssen, 2011). For example, data.gov currently hosts more than 450,000 datasets, up from the 47 datasets when the site was introduced.

Previous studies have emphasized the opportunities afforded by open data (Huijboom and den Broek, 2011). By promoting data openness, governments hope to enhance transparency, public participation, and collaboration (Nam, 2011). Essentially, these initiatives can serve to reduce information asymmetry between public agencies and their external stakeholders for the innovation of government services. Although datasets are in their raw form and may not have much value on their own, public agencies can leverage on businesses and citizens to contribute to the innovation of government services through the reorganizing, repackaging, and synthesizing information from various sources (DiFranzo et al., 2011). 
The role of government agencies in open data initiatives does not lie solely in the release of data. Other than increasing the variety and improving the quality of data made available to the public, there have been concurrent efforts by public agencies to motivate the use of open data for innovation activities by external stakeholders (Lee et al. 2012). A commonly used approach is through challenge competitions, where participants compete to provide the best idea or develop the most useful application with the available data. Winners are awarded prizes or other incentives such as recognition for their effort. For example, an European Union-wide open data competition was held for two months in 2011, which gathered a large number of entries aiming for the prize of 20,000 euros ${ }^{1}$.

However, beyond the buzz created through these ad-hoc initiatives and even with the efforts to improve data availability, it appears that the full potential of massive participation and collaboration to achieve innovation in government services has yet to materialize. Unlike the interest from the supply-side, the situation on the demandside seems to be less positive (Huijboom and Den Broek, 2011). Overall, it appears that there is a lack of external innovators making use of open data. As achieving a critical mass of such innovators is essential for a sustainable initiative, there is a need to understand what influences participation in open data.

\subsection{Research Question}

Following the increasing pace of open data initiatives globally, researchers are starting to investigate different aspects of this phenomenon in recent years. These include identifying the challenges of implementing open data (Huijboom and Den Broek, 2011; Janssen et al. 2012), key success factors of open data initiatives (European Commission, 2011), principles of open data (e.g., Sunlight Foundation, 2010), and proposing stage models for open data (Kalampokis et al., 2011).

However, most prior research in the area of open data has been either conceptual or practitioner-focused in nature and not based on theoretical foundations. Moreover, the majority of prior studies were conducted from the perspective of government agencies (supply-side), with little focus on external stakeholders (demand-side). Among the exceptions, Kuk and Davies (2011) observed various motivations of innovators participating in open data challenge competitions, but not for open data innovation in general. We contend that despite the potential of using open data to promote coinnovation between government agencies and external stakeholders, there is a lack of understanding of the perceptions of potential and current open data innovators. Specifically, research in open data has not explored what factors influence external stakeholders' decision to develop new applications and services with open data. Motivated thus, this paper seeks to answer the research question: What determines external stakeholders' behaviour to innovate with open data?

\subsection{Expected Contributions}

This study aims to contribute to research in open data by developing a model to provide insights into the factors that determine the innovation behaviour of external

${ }^{1}$ http: / / opendatachallenge.org/ 
stakeholders e.g., businesses and citizens. It will examine the effects of different motivators and inhibitors that influence peoples' willingness to innovate with open data. For government agencies, this study is expected to highlight important factors leading to the innovation of new services with open data, and if there are ways that they can help mitigate the barriers faced by their external stakeholders.

\section{Background and Previous Studies}

In this section, we provide a review of the relevant literature on open data. The search for relevant studies was conducted in several online journal databases (e.g., EBSCOHost, Science Direct), Google Scholar, and AIS Electronic Library. Terms such as "open data", "open government data", and "government 2.0" were used for the search with a period spanning from 2009 when the initiative first began to 2012. Subsequently, we review the past studies on open innovation and suggest how they apply to the study context.

\subsection{Open Data}

Open data initiatives involve making data produced or commissioned by government freely usable, reusable, and redistributable by anyone. Government agencies often embrace open data initiatives with the aim of promoting transparency, participation, and co-innovation (Nam, 2011).

In particular, public agencies seek to leverage their external stakeholders e.g., businesses and citizens, to further innovations in the area of electronic service delivery (Davies and Lithwick, 2010). Contributing to this trend is the increasing government recognition of the economic potential of open data. Vickery (2011) suggests that the economic value from the exploitation of open government data surpasses government investments in collecting and disseminating the data. From open data portals users will be able to access datasets generated for application development. In addition, government agencies may post a challenge online for users to solve. Table 1 lists a sample of open data initiatives and innovations developed with open data.

Table 1. Sample of Open Data Initiatives and Innovations

\begin{tabular}{|l|l|l|l|}
\hline Name & Link & Country & Description \\
\hline Government initiatives to promote innovation through data openness \\
\hline Data.go.kr & data.go.kr & South Korea & $\begin{array}{l}\text { Provides services al- } \\
\text { lowing the public to } \\
\text { take advantage of the } \\
\text { country's variety of } \\
\text { public information }\end{array}$ \\
\hline Data.gov & data.gov & USA & $\begin{array}{l}\text { Allows the public to } \\
\text { access datasets that are } \\
\text { generated and held by } \\
\text { the Federal } \\
\text { Government }\end{array}$ \\
\hline
\end{tabular}


Table 1. (continued)

\begin{tabular}{|c|c|c|c|}
\hline Data.gov.au & data.gov.au & Australia & $\begin{array}{l}\text { Provides an easy way to } \\
\text { find, access and reuse } \\
\text { public datasets from the } \\
\text { Australian Government } \\
\text { and state and territory } \\
\text { governments }\end{array}$ \\
\hline Open Kenya & opendata.go.ke & Kenya & $\begin{array}{l}\text { Allows the public to } \\
\text { obtain core government } \\
\text { development, demo- } \\
\text { graphic, statistical and } \\
\text { expenditure data avail- } \\
\text { able in a useful digital } \\
\text { format }\end{array}$ \\
\hline Overheid.nl & data.overheid.nl & Netherlands & $\begin{array}{l}\text { Allows the public to } \\
\text { obtain open govern- } \\
\text { ment data from the } \\
\text { national registry with } \\
\text { references to existing } \\
\text { open datasets }\end{array}$ \\
\hline $\begin{array}{l}\text { Portal de Da- } \\
\text { tos Públicos }\end{array}$ & datos.gob.cl & Chile & $\begin{array}{l}\text { Allows the people to } \\
\text { have access to informa- } \\
\text { tion based on which the } \\
\text { government makes } \\
\text { decisions for public } \\
\text { policy }\end{array}$ \\
\hline \multicolumn{4}{|c|}{ Business or citizen-driven innovations with government-released data } \\
\hline BUSit London & $\begin{array}{l}\text { data.gov.uk/apps/busit- } \\
\text { london }\end{array}$ & UK & $\begin{array}{l}\text { Uses London Bus data } \\
\text { from Transport for } \\
\text { London to plan your } \\
\text { multi-leg bus journey } \\
\text { in the capital }\end{array}$ \\
\hline CrimeReports & www.crimereports.com & USA & $\begin{array}{l}\text { Offers a family of af- } \\
\text { fordable, easy-to-use } \\
\text { software tools for law } \\
\text { enforcement agencies } \\
\text { to understand crime } \\
\text { trends and share current } \\
\text { neighbourhood crime } \\
\text { data with the public }\end{array}$ \\
\hline $\begin{array}{l}\text { Dunny Direc- } \\
\text { tories }\end{array}$ & $\begin{array}{l}\text { data.gov.au/apps/dunny- } \\
\text { directory/ }\end{array}$ & Australia & $\begin{array}{l}\text { A location based mo- } \\
\text { bile application, which } \\
\text { provides the ability to } \\
\text { easily locate public } \\
\text { toilets throughout Aus- } \\
\text { tralia. }\end{array}$ \\
\hline
\end{tabular}


Table 1. (continued)

\begin{tabular}{|l|l|l|l|}
\hline LiveTraffic & www.livetraffic.sg & Singapore & $\begin{array}{l}\text { Accesses data from } \\
\text { various government } \\
\text { sources to provide } \\
\text { customized real-time } \\
\text { navigation for drivers }\end{array}$ \\
\hline Park It DC & www.parkitdc.com & USA & $\begin{array}{l}\text { Allows user to check } \\
\text { a specific area in the } \\
\text { district capital for } \\
\text { parking information }\end{array}$ \\
\hline ShowNearBy & www.shownearby.com & Singapore & $\begin{array}{l}\text { A location-based ser- } \\
\text { vice delivering busi- } \\
\text { ness intelligence solu- } \\
\text { tions for Singapore's } \\
\text { private, people and } \\
\text { public sectors based on } \\
\text { public information } \\
\text { from the government }\end{array}$ \\
\hline
\end{tabular}

Very few studies have examined the open data phenomenon from the demand side. Using a combination of methods including field studies during open data events, survey, archival analysis, and interviews with open data innovators, Kuk and Davies (2011) identified several elements that facilitate and impede the use of open data among innovators. Respondents highlighted that most data provided by government agencies were of poor quality that had little value. Some of these issues relates to bad data formats, data releases that were not timely, or a lack of data granularity. However, despite the poor data quality, innovators were motivated by factors such as a desire for access to specific facts, having direct relevance and appeal to their needs, or the prospects of monetary rewards. Based on interviews with representatives from various ministries in the Netherlands, Janssen et al. (2012) surfaced several other factors inhibiting public use of open data such as the lack of explanation of the meaning of data, and the lack of knowledge to make sense of data.

The release of government data can spur the development of new services by external stakeholders, which is a recent way for governments to engage external parties in open innovation (Rossel et al., 2006).

\subsection{Open Innovation}

Organizations can perform open service innovation by engaging external stakeholders to contribute in developing new services or enhancing existing services based on ideas they generate or from the problems they encounter (Den Hertog, 2010). The concept of open innovation was introduced by Chesbrough (2003) to describe the shift from the closed innovation paradigm to a model where innovation ideas reside both internal and external to an organization. According to the closed innovation paradigm, organizations rely on internal $R \& D$ functions for discovery of new business 
opportunities. They attempt to achieve competitive advantage by utilizing internal knowledge for staying ahead of the competition and raising the barrier to entry for competitors. However, towards the end of the 20th century, the foundations of the closed innovation paradigm started to erode. With the blurring of boundaries between an organization and the environment, the open innovation paradigm has emerged acknowledging the increased porosity of knowledge flow.

Open innovation is defined as the use of purposive inflows and outflows of knowledge to accelerate internal innovation and expand the markets for external use of innovations, respectively (Chesbrough, 2006). With escalating R\&D costs and shortening product life cycles, organizations have come to realize that relying on internal innovation would negatively affect their competitive position (Keupp and Gassmann, 2009). Organizations can also benefit from adopting open innovation to achieve economies of scope and scale (Chesbrough, 2011).

Three main strategies can be seen in open innovation (Gassmann and Enkel, 2004). First, open innovation can be achieved with an inside-out strategy where firms bring ideas to the market by externalizing knowledge and transferring assets beyond the firm to stimulate external innovation. An example of this approach is the licensing of firms' intellectual property to external parties to gain additional revenue. Second, firms can engage in the outside-in strategy where the focus is to reach out to the external environment for acquiring resources such as knowledge. This is often performed with the realization that the abundance of external knowledge should be tapped to develop better products or services instead of relying on internal $R \& D$ (Boudreau and Lakhani, 2009). A popular approach here is crowdsourcing, where firms can post challenges online for external knowledge workers to tackle for a reward (Ye et al., 2012). Last, as a hybrid strategy, firms can adopt the coupled approach that combines both the outside-in and inside-out strategies to achieve synergy among different parties. This strategy often entails firm-level cooperation for the joint development of knowledge through arrangements such as joint ventures or alliances.

\section{Subsequent Work}

Although open innovation research has focused on the shift towards this paradigm in the private sector, governments are also getting involved in open innovation initiatives (Assar et al. 2011). However, unlike the private sector that is concerned with profits, the public sector aims to increase the benefits to its stakeholders and improve service delivery. Lee et al. (2012) examined open innovation initiatives in the some of the world's most innovative countries (e.g., USA, Canada, Singapore) and noted that they can either be government-led or community-led. In particular, open data initiatives were classified as government-led and adopting the inside-out open innovation strategy. The release of internal data assets by government agencies allows the leveraging of resources possessed by external stakeholders that agencies may not have in abundance. Open data facilitates open innovation in services because external parties now have access to government data to build useful applications for the public. Therefore, by adopting the open service innovation approach, new or enhanced services developed externally can benefit government agencies and the public alike. Despite the potential, Lee et al. (2012) noted that initiatives using the inside-out strategy de- 
serve more investigation, as they have received less research interest. Therefore, in response to this call, this study takes a deeper look into the factors influencing external stakeholders' decision to innovate with open data.

To identify and validate the influential factors, we plan to conduct multiple case studies of open data efforts at public agencies in Singapore. A multiple-case study design is preferred over a single-case study design for obtaining more compelling and robust data (Herriott and Firestone 1983). As an initial guide, we will review the suitability of previously found factors in prior literature of similar areas (e.g., Kuk and Davies, 2011; Janssen et al., 2012). Singapore is chosen for this study because of its leading status in eGovernment. In June 2011, the Singapore government announced data.gov.sg as its first-stop portal to search and access publicly-available data. The portal brings together over 5000 datasets from 50 government ministries and agencies. One of its key aims is to create value by catalysing application development by external parties. We intend to conduct in-depth case studies of such efforts to identify factors influencing participation in innovation activities. This research potentially has significant implications for both eGovernment researchers and practitioners in identifying the motivators and inhibitors of open data innovation.

\section{References}

Bommert, B.: Collaborative Innovation in the Public Sector. International Public Management Review 11(1), 15-33 (2010)

Boudreau, K., Lakhani, K.: How to Manage Outside Innovation. MIT Sloan Management Review 50(4), 69-76 (2009)

Chesbrough, H.W.: Open Innovation. In: The New Imperative for Creating and Profiting from Technology. Harvard Business School Press, Boston (2003)

Chesbrough, H.W.: Open Business Models - How to Thrive in a New Competitive Landscape. Harvard Business School Press, Boston (2006)

Chesbrough, H.W.: Open Services Innovation - Rethinking Your Business to Grow and Compete in a New Era. Jossey-Bass, San Francisco (2011)

Davies, A., Lithwick, D.: Government 2.0 and Access to Information: 2. Recent Developments in Proactive Disclosure and Open Data in the United States and Other Countries (Background paper) (2010), http: / /www . parl.gc.ca/Content/LOP/ResearchPublications / 2010-15-e.pdf

Den Hertog, P., Aa, W.V.D., De Jong, M.W.: Capabilities for Managing Service Innovation: Towards a Conceptual Framework. Journal of Service Management 21(4), 490-514 (2010)

Difranzo, D., Graves, A., Erickson, J.S., Ding, L., Michaelis, J., Lebo, T., Patton, E., Williams, G.T., Li, X., Zheng, J.G., Flores, J., McGuinness, D.L., Hendler, J.: The Web is My Backend: Creating Mashups with Linked Open Government Data. In: Wood, D. (ed.) Linking Government Data, pp. 205-219. Springer, New York (2011)

European Commission.: Pricing of Public Sector Information Study: Open Data Portals (E), Final Report (2011), http://ec.europa.eu/information_society/policy/ psi /docs/pdfs/report/11_2012/open_data_portals.pdf

Gassmann, O., Enkel, E.: Towards a Theory of Open Innovation: Three Core Process Archetypes. Paper Presented at the R\&D Management Conference (2004)

Herriott, R.E., Firestone, W.A.: Multisite Qualitative Policy Research: Optimizing Description and Generalizability. Educational Researcher 12(2), 14-19 (1983) 
Huijboom, N., den Broek, T.V.: Open Data: An International Comparison of Strategies. European Journal of ePractice 12, 4-16 (2011)

Janssen, K.: The Influence of the PSI Directive on Open Government Data: An Overview of Recent Developments. Government Information Quarterly 28(4), 446-456 (2011)

Janssen, M., Charalabidis, Y., Zuiderwijk, A.: Benefits, Adoption Barriers and Myths of Open Data and Open Government. Information Systems Management 29(4), 258-268 (2012)

Kalampokis, E., Tambouris, E., Tarabanis, K.: Open Government Data: A Stage Model. In: Janssen, M., Scholl, H.J., Wimmer, M.A., Tan, Y.-h. (eds.) EGOV 2011. LNCS, vol. 6846, pp. 235-246. Springer, Heidelberg (2011)

Keupp, M.M., Gassmann, O.: Determinants and Archetype Users of Open Innovation. R\&D Management 39(4), 331-341 (2009)

Kuk, G., Davies, T.: The Roles of Agency and Artifacts in Assembling Open Data Complementarities. Paper Presented at the International Conference on Information Systems, Shanghai (2011)

Lee, S.M., Hwang, T., Choi, D.: Open Innovation in the Public Sector of Leading Countries. Management Decision 50(1), 147-162 (2012)

Nam, T.: New Ends, New Means, but Old Attitudes: Citizens' Views on Open Government and Government 2.0. Paper Presented at the 44th Hawaii International Conference on System Sciences (2011)

Nam, T., Sayogo, D.S.: Government 2.0 Collects the Wisdom of Crowds. Social Informatics, 51-58 (2011)

Rossel, P., Finger, M., Misuraca, G.: Mobile e-Government Options: Between TechnologyDriven and User-centric. The Electronic Journal of e-Government 4(2), 79-86 (2006)

Sunlight Foundation.: Ten Principles of Opening Up Government Information (2010), http://assets.sunlightfoundation.com.s3.amazonaws.com/policy/ papers / Ten\%2 0 Principles $\% 2$ for $\% 20$ ppening 20 Up $\% 20$ Government $\%$ 20Data.pdf

Vickery, G.: Review of Recent Studies on PSI Re-Use and Related Market Developments (2011),

http://ec.europa.eu/information_society/policy/psi/docs/pdfs/ report/final_version_study_psi.docx

Ye., H., Kankanhalli, A., Yang, Z.: Knowledge Brokering for Open Innovation: A Case Study of Innovation Intermediaries. Paper presented at the International Conference on Information Systems, Orlando (2012) 